\title{
Glass Painting Art Learning Model by Utilizing Video to Improve Community's Appreciation and the Creativity of Creative Industry Actors
}

\author{
Nooryan Bahari, \\ Seni Rupa Murni, Fakultas Seni Rupa dan Desain, Univesitas \\ Sebelas Maret, Jl. Ir. Sutami No. 36 A, Kentingan, Jebres, \\ Surakarta, 57126, Indonesia
}

\author{
Desy Nurcahyanti \\ Seni Rupa Murni, Fakultas seni Rupa dan Desain, Univesitas \\ Sebelas Maret, Jl. Ir. Sutami No. 36 A, Kentingan, Jebres, \\ Surakarta, 57126, Indonesia
}

\begin{abstract}
The specific purpose of this study is to revitalize the art of glass painting in Indonesia through study, research and elaboration of glass painting materials that will be packaged in a modern way as a learning media in the form of video and innovation modules, in which some form of tradition art glass that has high difficulty level, packed into an attractive and easy medium to learn. The simple and easy to understand packaging is expected to improve the public interest to appreciate, preserve, and develop the glass painting arts. On the other hand, academic study of glass painting as as a potential of local art culture academically through visual arts model development activities is expected to encourage the actors glass painting to keep developing their creative process with college as a motivator and facilitator. The results of this study have been documented in several glass paintings by the creator on some of art centers such as Cirebon, Bantul, Yogyakarta, Karanganyar and Surakarta. The documented result are produced in the model of interactive DVD media to increase the public appreciation of glass painting, because this interactive video media has multilingual, multidimensional and multicultural properties so the utilization of video media innovation can improve the public appreciation and the creativity of glass painting artist to explore and share their works with the community.
\end{abstract} Keywords: learning media, glass painting, interactive, creative industry

\section{INTRODUCTION}

The current globalization is believed to have impacts on the life and culture of the Indonesian people. This condition causes the world to be without limits and might erase identity, national identity, and local or ethnic culture due to the strong influence of global culture. However, in certain respects, international cultural integration or interaction due to globalization can also be a source of national cultural enrichment when the combination are well organized and managed (UNS Art Team, 2010). One of the exploration of local culture concerns glass painting arts that need to developed into something that has high values of life. Through this endeavour, it is expected that glass paintings can be well documented and well appreciated by the society, and can continue to exist with high creativity

The development of glass painting information model by utilizing video media is one of the efforts to revitalize traditional arts and culture in Indonesia. In order to achieve these objectives, media and learning aids that are appropriate to the needs are required (Bahari, 2006: 8). The renewal of teaching methods through the use of video media is expected to increase public appreciation on glass painting and increase the creativity of actors in creative industry in general, especially the actors of glass painting. Learning method with video is a learning model that utilizes various learning media sources. Learning resources are processed into interactive, communicative and creative learning methods, which are VCD / DVD. This is because video media has the characteristics of multilingual, multidimensional, and multicultural that are needed in the making of media and audio visual based learning aids (Bahari, 2006: 9; Budiwiwaramulja, 2006: 1-2).

Audio-visual medium is known as a type of media that has a very large influence on its audience mainly due to the ability of a video camera to transfer various events or people's activities and actions into a audio visual form almost perfectly. Thanks to the advancement of optical and digital technology in the editing process, recorded video can now be modified according to the need. Thus it can be made to be far more dramatic than it really is. Likewise, the sound element has also reached the capacity of increasing the dramatic effect. The latest video image editing techniques even have the capacity to compile and compose recorded images into a completely different new image. Even imaginary images can be realized and not only limited to the original images. All of the video processing is adjusted with the purpose of making the video to lead the audience to comprehend the message that the video makers want to convey.

This type of arrangements is obvious in the fiction film genre. This type of film is capable of giving a tangible form of the subconscious (id) ideas or the expression of beautiful desires and fantasies, as well as our nightmares and fears. In documentary films, the use of video media elements such as sound recording capacity and cinematography are formally formulated to reproduce physical appearance of something, offering a perspective and interpretation of historical issues, processes and events. In this case, documentary film presents a form of reality that is not a truth to be explored, but as a social and historical reality that can be understood in the context of the source maker. 
The results of the study and research on batik painting and glass painting in Pekalongan and Cirebon under the framework of Exhibition of Technology and Innovation on Batik and Glass Paintings in Australia stated that like the glass paintings in Surakarta and Yogyakarta, the development of glass paintings in Cirebon undergoes transformation and revitalization. . In the 19th century, Cirebon glass paintings tended to take the themes of Wayang, Singa Barong Train, Paksi Nagaliman, Mega Mendung patterns, Islamic Calligraphy, pictures of Mosques, Buroq, and the like. Cirebon is one of the centerd of glass painting in Indonesia. Glass painting can grow rapidly in Cirebon because glass painting does not only function as a display element, but has fused with cultural traditions and served as a medium of expression for its painters. Glass painting function has shifted into documentation of cultural arts, religious, social life and spirituality of the Cirebon community. Glass painting is very well known as an Islamic da'wah media in the form of calligraphy glass paintings and wayang glass paintings. Cirebon glass paintings are painted with reverse painting techniques (painted from the back side), rich in color gradations and harmonizing decorative shades and displaying ornaments or various motifs such as Mega Mendung (Clouds) and Wadasan motifs that known as the typical motifs of Cirebon batik. The Cirebon glass painting is made in reverse from the back side of the glass field. It is different from some glass painters in Solo and Yogya who have painted them on the front side like painting on canvas. This shows that in terms of technique, glass painting in Ciebon is different from the others (Lansing, 1980). Even in Yogya the field of glass painting is not only on flat glass sheets, but also in curved, convex fields, as well as on functional objects such as glass, plates, vases and others.

\section{RESEARCH METHOD}

The research method used was interdisciplinary method, because the understanding of glass painting that only relies on one perspective does not seem to be sufficient. Interdisciplinary research is often qualitative, although in some parts it uses quantitative data that is treated as facts or evidence. The explanation was carried out in depth description regarding to the symptoms and relationships among them. Data assessment and overall explanation of the results of the research were carried out descriptively and holistically by interpretative and thorough conclusions (Jacques, 1980: 34-37).

The next method used after data were collected and initial data analysis were done, the method of creating art works was conducted to identify the need for synopsis writing, which is used in video recording and editing processes, as well as the structure of the video menu, and how to make it into an interactive VCD / DVD as a learning medium as well as an appreciation media and creations. This is because video media has multilingual, multidimensional and multicultural characteristics. Multilingual means video media aims to develop the ability to express themselves in various ways such as through visual language, sound, motion and combination (Barker, 1990: 65-69). Multidimensional means that video media develop basic competencies that include perception, knowledge, understanding, analyzing, evaluating, appreciating, and productivity in balancing the functions of the right and left brain, by combining elements of logic, ethics, and aesthetics, while multicultural means video media aim to develop appreciation for the diversity of local and global cultures such as the formation of attitudes of respect, tolerance, democratic, civilized and living harmoniously in a society with a pluralistic culture.

\section{DISCUSSION}

The results of observations, in-depth interviews and video documentation of several glass painters are data that are described in this discussion. Ninggar ASDI, whose real name is Ninggar Mayang Ningrum, who was born in Surabaya on January 19, 1985, is a graduate of Fine Arts undergraduate program and Cultural Studies graduate program of UNS. Since 2010 she has been active in teaching at the Indonesian Academy of Art and Design in Surakarta. Her introduction to glass painting art was when she visited the Interior Design department and saw transparent paint on a glass that created aesthetic elements. Initially Ninggar was not interested in a smooth and slippery glass medium, because she was more interested in textured media, in line with the pointilism technique that she mastered. When consulting for the Final Assignment, her lecturers saw her potential technique development that she mastered and suggested her to redirect her object of art works using glass medium with her topic of interest entitled Mata sebagai Titik Tolak Penciptaan Karya (Eyes as the departing point of an Art Work).

The next glass painter interviewed was Hermin Istiariningsih, a specialist painter of wayang beber, with mediums of canvas rolls and glass sheets. She is familiarly called as Mrs. Ning. Ning's traditional painting style, forms of puppets which are a deformation and elaboration of human figures, does not undergo re-deformation, nor is the use of color. The story of Panji is the basic theme of her painting object visualization. Story fragments per episode are drawn on sheets of fabric ranging from one meter to three meters. Especially for glass paintings, Mrs. Ning usually paints on glass measuring one and a half meters. There is almost no empty space in the painting with the wayang beber theme. Ornament motifs, flora and fauna shapes with traditional colors of red, golden, blue, and brown are the characteristics of her paintings. The detailed description of each figure is made carefully, including the motives and scenes that appear transparent. Mrs. Ning can be said to be very productive. She is able to complete a good wayang beber painting on fifty glass and cloth media for a period of one month, and not infrequently one Wayang Beber painting on cloth or glass in classical style could be finished in just one day and night.

In contrast to Ninggar and Bu Ning, Ratna Hadi is a glass painter born in Madiun on July 8, 1957, whose full name is Sriatie Ratnaningsih and married to Dwi Hadi Irianto who is a Helicopter Pilot. Ratna completed 
her general education in Ponorogo, then went on to the Fine Arts College (ASRI) in 1977 and took the Visual Communication Design Department. At the time of the lecture, Ratna was very diligent in working on graphic design, especially typography, which at that time was still a manual skill because the Computer graphic media had not been used. Many friends including her classmates used their skills to make letters or writing on their Final Assignment. Her perseverance is carried away until now which can be seen from her way in making glass painting in a curved field such as a bottle, glass or flower vase in a very small size.

There are two types of paints that can be used for glass painting. The first type of paint is the Opaque Coates paint. Before use, the paint is diluted first with thinner and added with a glass fixed catalyst of $\pm 5 \%$. The second one is Transparent Vetro paint which is a transparent and impressive type due to its bright and transparent colors. Its use can be immediately applied on the glass media that has been cleaned. It can also be melted with thinner if it is too thick. Glass media that has been drawn using an out liner, can be painted with Opaque Coates or Transparent Vetro paint. Good painting results are achieved using nylon brush. The brushed paint should not be too thick so that the results are flat. After the painting process is complete it can be heated in the oven with 120C-160C heat for 15-40 minutes, so that the paint can be firmly attached to the glass.

Based on the results of documenting the video data that has been done, then the production of the video recordings to make an Interactive DVD was carried out. This video editing process took a long time, because of the sorting process on the video documentation with long durations to make 30 minutes to a maximum of 60 minutes video. Although the duration was limited, the Interactive DVD must contain various information about the cultural settings of glass painting industry center, a brief history, the concept of making works, and the process of creation. On this limited duration, there must still be opening, content and closing like a documentary.

Documentary is considered as a recording of actuality, a piece of recording when the actual event takes place, when the person involved in it speaks, as real life as it was, spontaneous, and without intermediary media (Lansing, 1980). Although documentation and other elements are sometimes the main ingredient in the making of documentaries, these elements rarely becomes a dominant part of the entire documentary film itself, because all of these materials must be arranged, reprocessed and rearranged in their presentation structure. In the process of shooting a variety of choices must be taken by documentary filmmakers to determine the point of view, the size of the shot (type of shot), lighting, etc., in order to achieve the end result they want.

Documentary developments and genres are now very fast and diverse, but there are some elements that are fixed and their use which are the visual and verbal commonly used in documentaries, as follows:

1. Visual element among which: Reactive
observationalism which is the making of documentary films with direct material from subjects filmed.

2. Verbal element among which: aspects of overheard exchange, namely the recording of conversations between two or more sources that appear to be recorded accidentally (candid) and directly.

This study used software to create interactive video models namely Adobe Premiere Pro CS5, Adobe After Effect CS5, Cyberlink Power Director 8, and Cyberlink Power Producer 5. The reason for using Adobe Premiere Pro CS5 was because the software is a video editing application for professionals and common users who like video editing with simple interface which is easy to use. Adobe Premiere Pro CS5 is able to process and complete video production starting from capture, editing, effect, transition, and blend other effects professionally. While Adobe After Effect CS5 is used to create visual and motion graphic effects such as text and image animation. Adobe After Effect CS5 software can also be integrated with other Adobe software such as Adobe Photoshop and Adobe Illustrator.

Cyberlink Power Director 8 and Cyberlink Power Producer 5 in making this interactive video model were used to divide the menus of each episode because they have advantages of faster rendering process than Adobe Premiere Pro CS5. The burning process to DVD format this software could be done quickly. As with other software video editing Cylinklink Power Director 8 is able to process and complete video production from capture, editing, effects, transitions and other effects in a professional manner with moderate computer specifications.

The idea or basic concept of interactive video is indeed only a form of larger and wider driving force for change. The movement towards change is the main goal and not the video or the film itself as a product. However, as a tool, interactive video is not only treated as an ornamental item in the process towards the change. Some examples of the above episodes show that video is a tool that is inherent in the process of change, so there is no other way that anyone who will make and use interactive videos must obey the the principles as part of the education process and exchange of information in the community.

In the video media, the interaction is in the form of tutorials. Knowledge and information are displayed in small units. Tutorial forms of learning patterns are usually made in branch. Viewers are given the opportunity to choose video menu topics that they want to see or learn in a particular subject episode; the more topics in the video menu that can be selected to be seen or studied, the more choices and conveniences of the program that viewers can choose and absorb. The learning interaction in the tutorial form means that the information and knowledge are delivered and conditioned as in situations when viewers get face-toface information and knowledge.

\section{CONCLUSIONS}

Based on the description in the previous discussion, it can be concluded that several glass painting works and their artists have been documented in several 
centers of glass painting in Cirebon, Yogyakarta and Surakarta. The results of the documentation were embodied in an interactive DVD media model to increase public appreciation of glass painting. Interactive video media that was made has multilingual, multidimensional and multicultural characteristics.

The results of this study provide an alternative in learning the process of working with interactive video media. Although the structure of the video content structure is made in a coherent and easy to understand manner, it still requires guidance from a tutor. This video is expected to be a reference and guide for beginners in the creative glass painting industry. Innovation and novelty are made possible by combining several techniques. Education forums or communities, schools, training institutions are suitable parties to utilize the results of this study practically. Content and development are needed to continue this research. The involvement of various parties related to this activity will help develop practical (non-formal) learning in Indonesia.

\section{REFERENCES}

Bahari, Nooryan. 2006. Peningkatan Kualitas dan Inovasi Pembelajaran Melalui Media Rupa. Jurnal Seni Rupa edisi khusus, Februari 2006.

Barker, John et.al. 1990.The Interactive Learning Revolution: Multimedia in Education and Training, edited by Sanjaya Mishra and Ramesh C. Sharma. Hershey,London, Melbourne, Singapore: Idea Group Publishing.

Budiwiwaramulja, Dwi. 2006. Konsep Produksi Multimedia sebagai Penunjang Sarana Belajar Interaktif dalam Pendidikan Seni Rupa dan Kerajinan.Jurnal Seni Rupa edisi khusus, Februari 2006.

Jacques, R et.al. 1980. Design: Science Method. United Kingdom: Wesbury House.

Lansing, K.M. 1980. Art, Artist and Art Education. Iowa: Kendall/Hunt.

Tim Muhibah Seni UNS. 2010. Pengkajian Seni lukis Batik dan Kaca dalam rangka Gelar Produk Teknologi dan Inovasi Jurusan Seni Rupa FSSR UNS di Australia. Surakarta: Laporan Penelitian

FSSR

UNS. 